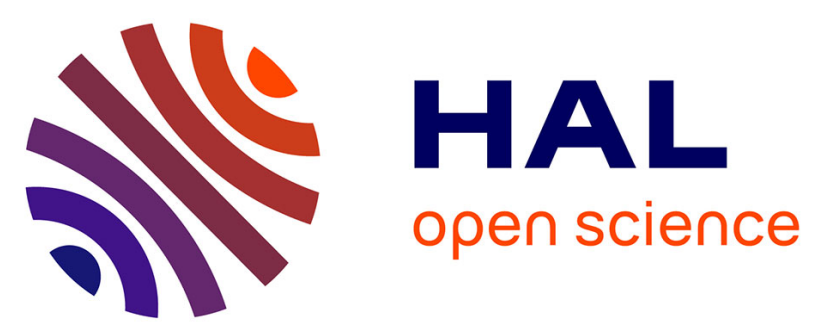

\title{
Serum lipid and apolipoprotein levels in four-year-old children are associated with parental serum lipid levels and track over time
}

\author{
Inger Ohlund, Olle Hernell, A Hornell, T Lind
}

\section{- To cite this version:}

Inger Ohlund, Olle Hernell, A Hornell, T Lind. Serum lipid and apolipoprotein levels in four-year-old children are associated with parental serum lipid levels and track over time. European Journal of Clinical Nutrition, 2011, 10.1038/ejcn.2011.14 . hal-00616528

\section{HAL Id: hal-00616528 \\ https://hal.science/hal-00616528}

Submitted on 23 Aug 2011

HAL is a multi-disciplinary open access archive for the deposit and dissemination of scientific research documents, whether they are published or not. The documents may come from teaching and research institutions in France or abroad, or from public or private research centers.
L'archive ouverte pluridisciplinaire $\mathbf{H A L}$, est destinée au dépôt et à la diffusion de documents scientifiques de niveau recherche, publiés ou non, émanant des établissements d'enseignement et de recherche français ou étrangers, des laboratoires publics ou privés. 


\section{Serum lipid and apolipoprotein levels in four-year-old children are} associated with parental levels and track over time

Öhlund Inger $\mathrm{PhD}^{\mathrm{ab}}$, Hernell Olle MD, $\mathrm{PhD}^{\mathrm{b}}$, Hörnell Agneta $\mathrm{PhD}^{\mathrm{a}}$, Lind Torbjörn $\mathrm{MD}, \mathrm{PhD}^{\mathrm{b}}$

$5 \quad{ }^{a}$ Department of Food and Nutrition, ${ }^{b}$ Department of Clinical Sciences, Pediatrics, Umeå University, S-901 87 Umeå, Sweden.

Running title Serum lipid levels in children

10

Corresponding address: Inger Öhlund, Department of Food and Nutrition, Umeå University, SE 90187 UMEÅ, Sweden.

Phone: +46-90-786 6560, fax: +46-90-7852135, e-mail : inger.ohlund@kost.umu.se

This study was supported by grants from the Goljes Memory Foundation, the Oskar Foundation, and the Mayflower Charity Foundation. 


\section{ABSTRACT}

Background/Objectives: There are only a few studies linking dietary fat intake to serum lipid

30 levels in young children. Our objective was to prospectively evaluate serum lipid levels from infancy to early childhood, and to explore their possible association with dietary, growth, and parental factors.

Methods: Children $(n=127)$ followed from early infancy were examined for serum lipid levels, anthropometry, and dietary intake at $4 \mathrm{y}$ of age. We also studied possible associations with

35 parental anthropometric and blood biochemistry data collected from 122 mothers' and 118 fathers' when children were 4 y of age. Results: Serum concentrations of total cholesterol (TC), high-density lipoprotein cholesterol (HDLC), low-density lipoprotein cholesterol (LDLC) and the apolipoprotein B/apolipoprotein A-1 ratio (apo B/apo A-1) showed significant tracking from infancy to 4 y. Furthermore, children's TC levels correlated with paternal TC level from 6 mo to

$404 \mathrm{y}$, but with maternal only at $4 \mathrm{y}$. In girls, both LDLC and HDLC correlated with parental LDLC and HDLC. In all children, intake of saturated fatty acids (SAFA) was higher than recommended, and in $90 \%$ of the children, polyunsaturated fatty acid (PUFA) intake was lower than recommended.

Conclusions: Serum lipid levels values tracked from infancy to $4 \mathrm{y}$ and were associated with

45 parental values. Higher serum lipid levels at 4 y compared to 6-18 mo of age may result from changes in the quality of dietary fat. We therefore suggest that intake of dietary fat in 4 y old children should be more focused on quality. Furthermore, as there were strong associations between the child and parental serum lipid levels this supports the view that family-based rather than individual intervention is preferable.

50 Keywords: Serum lipids, children, parental, dietary fat, tracking 


\section{INTRODUCTION}

The relationships between childhood dietary intake, serum lipid levels, obesity, and long-term risk for cardiovascular disease (CVD) are complex (Berenson et al., 1998; Burke et al., 2001;

55 Burke et al., 2005). Overweight children have lower levels of high-density lipoprotein cholesterol (HDLC) and higher levels of serum triglycerides (TG) compared to normal-weight children (Freedman et al., 1999; Burke et al., 2005).

Serum lipid levels differ between girls and boys already in early childhood, and dietary fat intake seems to affect girls and boys differently (Rogers et al., 2001; Niinikoski et al., 2007; Öhlund et

60 al., 2008). Total dietary fat intake, particularly higher intake of saturated fatty acids (SAFA), are positively associated with total serum cholesterol (TC) levels (Cowin et al,. 2001; Rogers and Emmett 2001; Niinikoski et al., 2007). Studies in Sweden (Enghardt et al., 2006; Garemo et al., 2006), as well as other countries (Agostoni et al., 2000; Cowin and Emmett 2001), report that intakes of SAFA are higher than the recommended $\leq 10 \%$ of total energy intake (10 E\%), while

65 intakes of polyunsaturated fatty acids (PUFA) are close to or below the recommended minimum intake of $5 \mathrm{E} \%$. Both tracking (associations over time) from early infancy and heredity may be additional important predictors of serum lipid levels later in life. In a longitudinal study, we followed healthy Swedish infants from 6 mo of age and found that a higher intake of PUFA was associated with lower total serum cholesterol (TC) and low-density lipoprotein cholesterol

70 (LDLC) levels at 12 mo (Öhlund et al., 2008). In this longitudinally followed study group, we investigated whether these associations remained later in life and whether there was any association with parental serum lipid levels.

The main objectives in the present follow-up study were to evaluate serum lipid levels from infancy to early childhood, i.e., 4 y of age; determine possible associations with dietary, growth, 
75 and parental factors; and examine possible tracking of serum lipid levels from infancy to childhood.

\section{METHODS}

\section{Study cohort}

80 This was a follow-up of 127 healthy children (63 girls and 64 boys) at $4 \mathrm{y}$ of age, who were prospectively followed from early infancy. Full details are published elsewhere (Lind et al., 2003; Öhlund et al.,2008).

Of the original 300 children 234 children (80\%) completed monthly dietary and anthropometrical registrations from 6 to 18 mo of age. These children and their parents were invited to participate

85 in the present follow-up study at 4 y of age starting in 2001. The parents of 127 children (54\%) consented to renewed dietary, anthropometric, and biochemical measurements of the children. Of the parents, 240 (122 mothers and 118 fathers) consented to anthropometric and biochemical measurements when their child was $4 \mathrm{y}$. Mean maternal and paternal age was $33.7 \mathrm{y} \mathrm{(4.5)} \mathrm{and}$ 35.3 y (5.5), respectively. The participating 4-y-olds were not different from the non-participating

90 children with respect to weight and length at birth, $12 \mathrm{mo}$, and $18 \mathrm{mo}$; duration of breastfeeding; or with respect to dietary fat intake and serum lipid levels at 12 and 18 mo. However, a higher proportion of parents had university educations among the families who participated in the 4-y follow-up compared to those who did not $(33 \%$ vs. $25 \%, p<0.001)$. Of the 107 non-participating children, 12 were sick at the follow-up, 16 had moved from the area; of the remainder, the

95 parents declined to participate without explanation.

The study was approved by the local Ethics Committee of the Faculty of medicine, Umeå University, Sweden. 


\section{Anthropometric data and biochemical analyses}

100 Between 6-18 mo, the participating children were measured monthly. They were weighed to the nearest $0.01 \mathrm{~kg}$ using a Seca 835 digital baby scale, and recumbent length was measured to the nearest millimeter using a Harpenden infantometer (CMS Weighing Equipment, London, UK). At $4 \mathrm{y}$, weight was measured to the nearest $0.1 \mathrm{~kg}$ using a Seca 835 digital adult scale (Seca, Hamburg, Germany) and height to the nearest millimeter was measured using a CMS stadiometer

105 (CMS Weighing Equipment). Mid upper-arm circumference was measured using a plastic measuring tape. Subcutaneous fat was measured by subscapular and triceps skin-fold thickness using a Harpenden skinfold caliper (Baty International, West Sussex, UK).

Body mass index (BMI) was calculated and cut-off levels for overweight/obesity in children were set separately for girls and boys using the definition suggested by the International Obesity Task

110 Force (Cole et al., 2000). These cut-off points for overweight and obesity (iso-BMI $\geq 25$ and $\geq$ 30, respectively) were adjusted for age and gender and corresponded to the well-known thresholds of $\mathrm{BMI} \geq 25 \mathrm{~kg} / \mathrm{m}^{2}$ and $\mathrm{BMI} \geq 30 \mathrm{~kg} / \mathrm{m}^{2}$ for overweight and obesity, respectively, among adults.

115 Venous blood samples were taken at least $2 \mathrm{~h}$ after a meal from the children at 6, 12, and 18 mo, and at $4 \mathrm{y}$ they were taken while the children and their parents were in a fasting state. Sera were stored at $-20{ }^{\circ} \mathrm{C}$ until analysis. Serum lipids were analysed for TC, HDLC, apolipoprotein A-1 (apo A-1), apolipoprotein B (apo B), and TG by the Roche/Hitachi method, which is the routine analysis method used at the department of Clinical Chemistry at Umeå University hospital.

120 LDLC was calculated using the Friedewald formula (Friedewald Levy and Fredrickson 1972).

\section{Dietary assessment}


We assessed dietary intake in the children using monthly 5-d food records from 6 to 18 mo and

125 then once at the 4 y follow-up. Product names were used; for example, the names of spreads, ice creams, candies, yogurts, and meals at fast-food restaurants. The parents used a booklet with photos of serving sizes of meals, snacks, etc., but also used standard household measures for quantities as described earlier (Lind et al., 2003). If the participating child attended day care, the dietitian visited the centre to inform the staff of how to record dietary intake. Data regarding

130 breastfeeding were recorded prospectively, except for children who had stopped breastfeeding before inclusion in the study at 6 mo of age. Each intake of breast milk was recorded either as a “meal” or a "snack" estimated as $134 \mathrm{ml}$ per meal up to 8 mo of age, then $102 \mathrm{~g}$ per meal beyond $8 \mathrm{mo}$, and as $25 \mathrm{~g}$ per snack at all ages (Lind et al., 2003). Nutrient intakes from breast milk were calculated in accordance with Jensen (1995) and Tsang et al. (1997). Breastfeeding at 6 mo was

135 recorded as exclusive if no other foods were introduced, and partial if foods or formula had been introduced. Breastfeeding duration was used for establishing associations between breastfeeding and serum lipid levels. Energy and nutrient intake were calculated with the MATs S406 software program (Rudans Lättdata, Västerås, Sweden), which uses the food composition database of the Swedish National Food Administration, as well as special products for children and other

140 products not included in the original database. Dietary fat intakes were described as percent of total energy (E\%) and PUFA, mono saturated fatty acids (MUFA), and SAFA were described as proportions $(\%)$ of total fat. To evaluate the accuracy of the reported energy intake, we calculated the ratios of energy intakes (EI) to basal metabolic rate (BMR) in girls and boys (Livingstone et al., 2003).

145

\section{Calculations and statistical analyses}


Statistical analyses were performed using SPSS 15.0 (SPSS, Chicago, IL, USA). Mean and standard deviation (SD) were used to describe serum lipid and apolipoprotein levels and dietary fat intakes. Gender difference and changes in dietary fat intake over time were analysed by

150 Student's $t$-test. The skinfold measurements were skewed and were therefore log transformed before analysis. Pearson's correlation was used to analyse associations of serum lipids over time (tracking) and their association with parental levels. Paired sample t-test was used for changes in variables over time. Data reduction of dietary fat intakes were used and presented as mean daily intakes during the 6-9 mo, 10-14 mo, 15-18 mo and 4 y periods. The relationships between

155 serum lipids and apolipoprotein levels at $4 \mathrm{y}$ and dietary fat intake from $6 \mathrm{~m}$ to $4 \mathrm{y}$, duration of breastfeeding, the child's BMI at $4 \mathrm{y}$, parental serum lipid levels, and parental BMI were investigated using univariate regression analysis. Factors significantly associated $(p \leq 0.05)$ with the childrens serum lipids and ApoB/apoA-1 levels in the univariate analysis were included in a stepwise multivariate regression analyze.

\section{RESULTS}

\section{Serum lipids and anthropometrics}

Mean TC levels were stable during infancy. From 18 mo to 4 y, serum TC, LDLC, HDLC, ApoA-1, and ApoB levels increased $(\mathrm{p} \leq 0.001)$ while TG levels decreased $(\mathrm{p} \leq 0.001)$ (Table 1).

165 The TC, HDLC, LDLC, Apo A-1 and Apo B levels as well as the TC/HDLC and Apo B/Apo A1 ratios showed significant tracking over time. Furthermore, the children's TC levels were correlated with their father's TC level from 6 mo- 4 y, but with their mother's only at $4 \mathrm{y}$. At $4 \mathrm{y}$, girls' but not boys' HDLC was positively correlated with maternal HDLC. Furthermore girls', but not boys' LDLC levels were positively correlated with parental LDLC. (Table 2) 
170 At $4 \mathrm{y}, 16 \%$ of the children were overweight (iso-BMI $\geq 25$ ) with no gender difference. Among parents, overweight was more common among fathers compared to mothers $(47 \%$ vs $28 \%, p<$ 0.05). BMI in children was positively correlated with mid-upper arm circumference $(r=0.80, p<$ $0.001)$, subscapularis skinfold $(r=0.58, p<0.001)$, and triceps skinfold $(r=0.66, p<0.001)$. No correlations were found between the children's serum lipid levels and growth rate, any of the

175 other anthropometric parameters, or parental BMI (data not shown).

At $4 \mathrm{y}$, TC levels $>5.2 \mathrm{mmol} / 1$ were observed in $22 \%$ (seven boys and 17 girls) of the children, in $49 \%$ of the fathers, and in $32 \%$ of the mothers. LDLC $>3.34 \mathrm{mmol} / 1$ was observed in $24 \%$ of the children. The children with higher TC ( $>5.2 \mathrm{mmol} / \mathrm{l})$ had significantly higher LDLC, HDLC, and apo B levels and apo B/apo A1-ratios, compared to children with TC $<5.2 \mathrm{mmol} / \mathrm{l}$ (data not 180 shown).

\section{Dietary intakes}

At 6 mo, five infants were exclusively breastfed, 97 were partially breastfed, and 24 no longer breastfed. The mean (SD) duration of breastfeeding was 8.7 (3.4) mo, and two children had not

185 been breastfed at all. Mean (SD) daily energy intake at 4 y was 1462 (240) and 1382 (228) kcal per day in boys and girls, respectively; the calculated ratio of mean EI:BMR was 1.61 in both boys and girls.

Mean dietary fat intake decreased from $42 \mathrm{E} \%$ at 6 mo to $33 \mathrm{E} \%$ at 4 y (Table 3). However, as dietary fat $(\mathrm{E} \%)$ decreased, the proportion of SAFA increased significantly $(\mathrm{p} \leq 0.001)$, whereas

190 the proportions of MUFA and PUFA decreased $(p \leq 0.001$ and $p \leq 0.001)$ (Figure 1). The intake of SAFA was higher than recommended in all children and the intake of PUFA was lower in most of the children (NNR 2004). At $4 \mathrm{y}$, none of the children had an intake of SAFA below the 
recommended upper level of $10 \mathrm{E} \%$ whereas only $10 \%$ of the children had a total PUFA intake above the recommended lower level of $5 \mathrm{E} \%$. For most children, the intake of MUFA was within 195 the recommended limits (NNR 2004).

Associations between children's serum lipid levels and dietary fat intake, and parental serum lipids.

At 6 mo, children who were still partially or exclusively breastfed had higher TC levels compared 200 to those who were not breastfed $(p<0.001)$, but the difference did not remain at $12 \mathrm{mo}, 18 \mathrm{mo}$, or 4 y. Factors associated with children's serum lipid levels were analysed using regression analysis in two models (Table 4 and 5). The serum levels of TC, LDLC, and HDLC, and the apo B/apo A-1 ratio were used as dependent variables. Independent variables with $(p<0.05)$ in the univariate model were included in a multivariate model. The child's serum lipid levels at 4 y 205 were associated with both parents' serum lipid levels in the univariate model and in the final multivariate model the child's TC and LDLC were associated with paternal TC and LDLC levels and the child's HDLC with maternal HDLC levels. Duration of breastfeeding was negatively associated with HDLC and positively associated with the apoB/apoA-1 ratio in the univarate model but this did not remain in the multivariate analysis. Higher intake of SAFA before 18 mo

210 was associated with a higher apoB/apoA-1 ratio. In opposite, a higher intake of unsaturated fatty acids (MUFA at 10-14 mo and 15-18 mo, and PUFA at 10-14 mo) was associated with a lower apoB/apoA-1 ratio in the univariate model. In the final analysis, higher intake of SAFA 10-14 mo remained positively associated with the child's apoB/apoA-1 ratio. 


\section{DISCUSSION}

The main finding in the present study was the correlation between child and parental serum lipid levels. In the study group, which comprised children with a high intake of SAFA and a low intake of PUFA compared to recommended guidelines, TC levels above the cut-offs for abnormal

$220 \mathrm{TC}(>5.2 \mathrm{mmol} / \mathrm{l})$ (Daniels et al., 2008) were present in $22 \%$ of the children, $49 \%$ of the fathers, and $32 \%$ of the mothers. Furthermore, $24 \%$ of the children had LDLC $>3.35 \mathrm{mmol} / \mathrm{l}$, defined as a risk factor for adult dyslipidemia and associated cardiovascular disease (CVD) (Nicklas et al., 2002; Jolliffe and Janssen 2006). This calculated risk factor in the present study group was 4-fold higher compared to the risk factor calculated for the Bogalusa Heart Study (Nicklas, von

225 Duvillard and Berenson 2002). Over time, serum TC, LDLC, HDLC, ApoA-1, and ApoB levels increased significantly. In a previous paper, we reported that a higher intake of PUFA was associated with lower TC and LDLC levels at 12 mo (Öhlund et al., 2008). However, three years later, at $4 \mathrm{y}$ of age, the associations between dietary fat intake and serum lipids and apolipoproteins were weak. Compared with Finnish children on a restricted, low-fat diet

230 (Niinikoski et al., 2007), these children had more favourable lipid levels at 12 mo (Öhlund et al., 2008), but this did not remain until $4 \mathrm{y}$ of age. The reason may be that during the period 6 mo to $4 \mathrm{y}$, there was a deterioration in the quality of dietary fat intake. Although total dietary fat intake decreased from 6 mo to $4 \mathrm{y}$, the proportion of SAFA (\%) increased whereas the proportions of both MUFA and PUFA (\%) decreased with decreasing dietary fat (E\%) resulting in lower fat of

235 quality by $4 \mathrm{y}$ of age. Thus there was an inverse relationship, between decreases in the intakes of PUFA and MUFA and increases in the TC and LDLC levels. Moreover, quality of dietary fat intake at 10-18 mo was associated with the apo B/apoA-1 ratio. A higher intake of SAFA at 1014 mo and 15-18 mo was associated with higher apo B/apoA-1 ratios, and a higher intake of 
MUFA and PUFA was associated with lower apo B/apoA-1 ratios at 4 y of age. To our

240 knowledge, few studies have examined associations between dietary patterns and apo B/apoA-1 ratios (Kurvinen et al., 2005); more surveys should be performed.

Another finding of our study was tracking of serum lipids from infancy to early childhood. TC and HDLC levels and apo B/apo A-1 ratios tracked from 6 mo to 4 y. Tracking of the apo B/apo A-1 ratio was strongest, and was stronger in boys than in girls. Apo B and apo A-1 levels and

245 their ratio are possibly superior to TC, HDLC, and LDLC levels in terms of predicting CVD (Estonius et al., 2005; Kallner et al., 2006). Although there are limited data regarding the association between childhood apo B/apo A-1 ratios and long-term effects on CVD risk, they are suggested to have high predictive value in paediatric risk assessments (Frontini et al., 2008; Juonala et al., 2008). Tracking of serum lipids in Swedish children has not been reported 250 previously, but our results are in agreement with the Finnish STRIP study (Rask-Nissila et al., 2002). Further, tracking of serum lipids from childhood into adulthood was demonstrated by the Bogalusa Heart Study (Nicklas, von Duvillard and Berenson 2002). This supports the importance of early interventions in families with known raised serum lipid levels and known CVD risk (Magnussen et al., 2008). However, the cut-off levels for risk assessments in children are not yet 255 clear, although guidelines have been developed by the United States National Heart, Lung and Blood Institute's Pediatric Cardiovascular Risk Reduction Initiative (Kwiterovich 2008).

There were no correlations between the children's serum lipid levels, growth rate, BMI, or parental BMI. This is in accord with a British study in which central obesity, but not BMI, was 260 negatively associated with HDLC levels in boys and positively associated with LDLC levels in girls (Cowin et al., 2000). 
A strength of our study is that it was based on prospective longitudinal data for anthropometric and biochemical variables and carefully repeated registrations of dietary intake of the children. A

265 further strength of the study is the anthropometric and biochemical data collected from the parents when the child was $4 \mathrm{y}$. However, some limitations of this study should be noted. We have no data regarding the physical activity of the children and parents, and no data regarding the parents' diet and could not analyse whether the associations between the child's and their parents are based on diet or genetic factors . Furthermore, we were unable to include more than 127 out

270 of the original 234 children in the follow-up study. The by far most common reason for not participating in the follow-up study was lack of time/willingness to do another 5-day period of diet recording, which may lead to a selection bias. However there were no differences, except for the parents' education level, between the participating and non-participating children when compared at 12 and 18 mo. In addition, assessment of dental health at 4 y compared with

275 population data suggested that there was no significant selection bias affecting the present followup (Öhlund et al., 2007). However, we cannot exclude that parents accepting to participate were more health concerned or had higher health awareness than those who did not. . In conclusion, serum lipid and apolipoprotein levels tracked from infancy to $4 \mathrm{y}$, and the strongest tracking was for the apo B/apo A-1 ratio. Higher serum lipid levels at 4 y compared to 280 6-18 mo of age may, at least partly, result from changes in the quality of dietary fat. We therefore suggest that intake of dietary fat in 4 y old children should be more focused on quality. Furthermore, as there were strong associations between the child and parental serum lipid levels this supports the view that family-based rather than individual intervention is preferable. 


\section{Acknowledgements}

285 The authors are most grateful to all of the participating children and their parents, and to research nurse Margareta Henriksson for help with collecting the data. We also thank associate professor Hans Stenlund, Department of Public Health and Clinical Medicine, Epidemiology and Public Health Sciences, Umeå University, for invaluable statistical support.

\section{Conflicts of Interests}

The authors declare no conflict of interest. 


\section{REFERENCES}

Agostoni C, Riva E, Scaglioni S, Marangoni F, Radaelli G and Giovannini M (2000). Dietary fats and cholesterol in italian infants and children. Am J Clin Nutr 72 (Suppl 5): 1384S-1391S.

Berenson GS, Srinivasan SR and Nicklas TA (1998). Atherosclerosis: a nutritional disease of childhood. Am J Cardiol 82: 22T-29T.

Burke V, Beilin LJ and Dunbar D (2001). Family lifestyle and parental body mass index as predictors of body mass index in Australian children: a longitudinal study. Int J Obes Relat Metab Disord 25: 147-57.

Burke V, Beilin LJ, Simmer K, Oddy WH, Blake KV, Doherty D, et al. (2005). Predictors of body mass index and associations with cardiovascular risk factors in Australian children: a prospective cohort study. Int J Obes (Lond) 29: 15-23.

Cole TJ, Bellizzi MC, Flegal KM and Dietz WH (2000). Establishing a standard definition for child overweight and obesity worldwide: international survey. BMJ 320: 1240-3.

Cowin I and Emmett P (2000). Cholesterol and triglyceride concentrations, birthweight and central obesity in pre-school children. ALSPAC Study Team. Avon Longitudinal Study of Pregnancy and Childhood. Int J Obes Relat Metab Disord 24: 330-9.

Cowin IS and Emmett PM (2001). Associations between dietary intakes and blood cholesterol concentrations at 31 months. Eur J Clin Nutr 55: 39-49.

Daniels SR and Greer FR (2008). Lipid screening and cardiovascular health in childhood. Pediatrics 122: 198-208.

Enghardt BH, Pearson M and Becker W (2006). Dietary habits and nutrient intake in Swedish children 4 year old and school children in grade 2 and 5 (Riksmaten - barn 2003) Uppsala, National Food Administration (Livsmedelsverket), Uppsala, Sweden. 
Estonius M and Kallner A (2005). How do conventional markers of lipid disorders compare with apolipoproteins? Scand J Clin Lab Invest 65: 33-44.

Freedman DS, Dietz WH, Srinivasan SR and Berenson GS (1999). The relation of overweight to cardiovascular risk factors among children and adolescents: the Bogalusa Heart Study. Pediatrics 103: 1175-82.

Fridewald WT (1972). Estimation of the Concentration of Low-Density Lipoprotein Cholesterol in Plasma, Without Use of the Preparative Ultracentrifuge. Clin Chem 18: 499-502.

Frontini MG, Srinivasan SR, Xu J,Tang R, Bond MG and Berenson GS (2008). Usefulness of childhood non-high density lipoprotein cholesterol levels versus other lipoprotein measures in predicting adult subclinical atherosclerosis: the Bogalusa Heart Study. Pediatrics 121: 924-9.

Garemo M, Palsdottir V and Strandvik B (2006). Metabolic markers in relation to nutrition and growth in healthy 4-y-old children in Sweden. Am J Clin Nutr 84: 1021-6.

Jensen RG (1995). Handbook of milk composition. Inc., San Diego.

330 Jolliffe CJ and Janssen I (2006). Distribution of lipoproteins by age and gender in adolescents. Circulation 114: 1056-62.

Juonala M,Viikari JS, Kahonen M, Solakivi T, Helenius H, Jula A, et al. (2008). Childhood levels of serum apolipoproteins B and A-I predict carotid intima-media thickness and brachial endothelial function in adulthood: the cardiovascular risk in young Finns study. $J$ Am Coll Cardiol 52: 293-9.

Kallner A and Estonius M (2006). [Measurement of apolipoproteins is better than routinely measured traditional lipids]. Läkartidningen 103: 753-6, 758. 
Kurvinen E, Aasvee K, Zordania R, Jauhiainen M and Sundvall J (2005). Serum lipid and apolipoprotein profiles in newborns and six-year-old children: the Tallinn Young Family Study. Scand J Clin Lab Invest 65: 541-50.

Kwiterovich PO (2008). Cut points for lipids and lipoproteins in children and adolescents: should they be reassessed? Clin Chem 54: 1113-5.

Lind T, Lönnerdal B, Persson LÅ, Stenlund H, Tennefors C and Hernell O (2003). Effects of weaning cereals with different phytate contents on hemoglobin, iron stores, and serum zinc: a randomized intervention in infants from 6 to 12 mo of age. Am J Clin Nutr 78: $168-75$.

Livingstone MB and Black AE (2003). Markers of the validity of reported energy intake. $J$ Nutr: 895S-920S.

Magnussen CG, Raitakari OT, Thomson R, Juonala M, Patel DA, Viikari JS, et al. (2008). Utility of currently recommended pediatric dyslipidemia classifications in predicting dyslipidemia in adulthood: evidence from the Childhood Determinants of Adult Health (CDAH) study, Cardiovascular Risk in Young Finns Study, and Bogalusa Heart Study. Circulation 117: 32-42.

Nicklas TA,von Duvillard SP and Berenson GS (2002). Tracking of serum lipids and lipoproteins from childhood to dyslipidemia in adults: the Bogalusa Heart Study. Int J Sports Med 23 (Suppl 1): S39-43.

Niinikoski H, Lagström H, Jokinen E, Siltala M, Rönnemaa T, Viikari J, et al. (2007). Impact of repeated dietary counseling between infancy and 14 years of age on dietary intakes and serum lipids and lipoproteins: the STRIP study. Circulation 116: 1032-40.

360 NNR (2004). Nordic Nutrition recommendations 2004. Copenhagen, Nordic council of ministers. 
Ohlund I, Holgerson PL, Backman B, Lind T, Hernell O and Johansson I. (2007). "Diet intake and caries prevalence in four-year-old children living in a low-prevalence country." Caries Res 41: 26-33.

Ohlund I, Hörnell A, Lind T and Hernell O (2008). Dietary fat in infancy should be more focused 365 on quality than on quantity. Eur J Clin Nutr 62: 1058-64.

Rask-Nissila L, Jokinen E,Viikari J, Tammi A, Ronnemaa T, Marniemi J, et al. (2002). Impact of dietary intervention, sex, and apolipoprotein E phenotype on tracking of serum lipids and apolipoproteins in 1- to 5-year-old children: the Special Turku Coronary Risk Factor Intervention Project (STRIP). Arterioscler Thromb Vasc Biol 22: 492-8.

370 Rogers IS and Emmett PM (2001). Fat content of the diet among preschool children in southwest Britain: II. relationship with growth, blood lipids, and iron status. Pediatrics 108: E49. Tsang RC,Zlotking S,Nichols BL and Hansen JW (1997). Nutrition during infancy. Inc., Cincinnati. 
385

TABLES 1- 4 
Table 1. Mean serum lipid and apolipoprotein levels in children from 6 mo to $4 \mathrm{y}$ and their parents. Data provided as mean (SD).

\begin{tabular}{|c|c|c|c|c|c|c|c|c|c|c|}
\hline & \multicolumn{2}{|c|}{$6 \mathrm{mo}$} & \multicolumn{2}{|c|}{$12 \mathrm{mo}$} & \multicolumn{2}{|c|}{$18 \mathrm{mo}$} & \multicolumn{2}{|c|}{$4 y^{* * *}$} & & \\
\hline & $\begin{array}{l}\text { Boys } \\
(n=58)\end{array}$ & $\begin{array}{l}\text { Girls } \\
(n=61)\end{array}$ & $\begin{array}{l}\text { Boys } \\
(n=55)\end{array}$ & $\begin{array}{l}\text { Girls } \\
(n=57)\end{array}$ & $\begin{array}{l}\text { Boys } \\
(n=58)\end{array}$ & $\begin{array}{l}\text { Girls } \\
(n=61)\end{array}$ & $\begin{array}{l}\text { Boys } \\
(n=50)\end{array}$ & $\begin{array}{l}\text { Girls } \\
(n=58)\end{array}$ & $\begin{array}{l}\text { Mothers }{ }^{\prime 1} \\
(n=120)\end{array}$ & $\begin{array}{l}\text { Fathers }^{1} \\
(n=115)\end{array}$ \\
\hline $\mathrm{TC}(\mathrm{mmol} / \mathrm{l})$ & $3.36(0.65)$ & $3.50(0.76)$ & $3.32(0.67)$ & $3.46(0.63)$ & $3.46(0.70)$ & $3.59(0.60)$ & $4.48(0.94)$ & $4.68(0.69)$ & $4.82(0.90)$ & $5.23(0.89)$ \\
\hline $\operatorname{LDLC}(\mathrm{mmol} / \mathrm{l})$ & $1.52(0.73)$ & $1.69(0.76)$ & $1.74(0.52)$ & $1.76(0.62)$ & $1.84(0.58)$ & $2.00(0.58)$ & $2.77(0.60)$ & $2.92(0.61)$ & $2.77(0.72)$ & $3.32(0.75)$ \\
\hline $\operatorname{HDLC}(\mathrm{mmol} / \mathrm{l})$ & $0.94(0.27)$ & $0.86(0.21)$ & $0.90(0.32)$ & $0.90(0.19)$ & $0.96(0.30)$ & $0.89(0.23)$ & $1.33(0.23)$ & $1.39(0.22)$ & $1.56(0.4)$ & $1.30(0.32)$ \\
\hline apoA-1 (g/l) & $1.02(0.20)$ & $0.97(0.14)$ & $0.93(0.22)$ & $0.95(0.12)$ & $0.95(0.21)$ & $0.91(0.14)$ & $1.2(0.20)$ & $1.2(0.19)$ & $\mathrm{n} / \mathrm{a}$ & $\mathrm{n} / \mathrm{a}$ \\
\hline apoB (g/l) & $0.67(0.18)^{*}$ & $0.75(0.21)^{*}$ & $0.68(0.15)$ & $0.72(0.16)$ & $0.72(0.15)$ & $0.77(0.15)$ & $0.79(0.15)$ & $0.83(0.16)$ & $\mathrm{n} / \mathrm{a}$ & $\mathrm{n} / \mathrm{a}$ \\
\hline apoB/apoA1 & $0.71(0.44)$ & $0.79(0.26)$ & $0.85(0.82)$ & $0.87(0.24)$ & $0.91(1.14)$ & $0.87(0.24)$ & $0.69(0.25)$ & $0.69(0.16)$ & $\mathrm{n} / \mathrm{a}$ & $\mathrm{n} / \mathrm{a}$ \\
\hline TG (mmol/l) & $1.96(0.88)$ & $2.12(0.97)$ & $1.49(0.72)$ & $1.77(0.86)$ & $1.47(0.87)$ & $1.54(0.57)$ & $0.85(0.50)$ & $0.83(0.31)$ & $1.06(0.54)$ & $1.33(0.62)$ \\
\hline
\end{tabular}

Abbreviations: TC, total cholesterol; HDLC, high-density lipoprotein cholesterol; LDLC, low-density lipoprotein cholesterol; apo A-1, apolipoprotein A-1 and apo B, apolipoprotein B

${ }^{1}$ Parental serum lipids assessed when child was 4 y old, maternal mean age was 33.7 (4.5) y and paternal 35.3 (5.5) y. Apolipoprotein A1(apoA-1) and apolipoproteinB (apoB) not available (n/a) for mothers' and fathers'. No significant differences in apoB/apoA1 between 4 y old boys and younger age groups. ${ }^{*} p<0.05$ between gender at 6 mo. No significant differences between gender at $12 \mathrm{~m}, 18 \mathrm{~m}$, and 4 y. ${ }^{* * *}$ All differences in serum lipids between 4 y of age and the younger ages are significant at $\mathrm{p} \leq 0.001$ unless otherwise stated. 
Table 2. Tracking of children's serum lipid and apolipoprotein levels and associations with parental values, measured when children were 4 y old.

\begin{tabular}{|c|c|c|c|c|c|c|c|c|}
\hline & $6 \mathrm{mo}^{1}$ & & $12 \mathrm{mo}^{1}$ & & $18 \mathrm{mo}^{1}$ & & 4 years $^{1}$ & \\
\hline & $\begin{array}{l}\text { Boys } \\
(n=61)\end{array}$ & $\begin{array}{l}\text { Girls } \\
(n=62)\end{array}$ & $\begin{array}{l}\text { Boys } \\
(n=52)\end{array}$ & $\begin{array}{l}\text { Girls } \\
(n=56)\end{array}$ & $\begin{array}{l}\begin{array}{l}\text { Boys } \\
(n=58)\end{array} \\
\end{array}$ & $\begin{array}{l}\text { Girls } \\
(n=60)\end{array}$ & $\begin{array}{l}\text { Boys } \\
(n=47)\end{array}$ & $\begin{array}{l}\text { Girls } \\
(n=57)\end{array}$ \\
\hline \multicolumn{9}{|l|}{ TC } \\
\hline$\overline{6 \mathrm{mo}}$ & & & $0.41 * *$ & $0.57 * * *$ & $0.32 *$ & $0.41 * *$ & $0.32 *$ & $0.43 *$ \\
\hline 12 mo & & & & & $0.62 * * *$ & $0.55 * * *$ & $0.50 * * *$ & $0.57 * * *$ \\
\hline $18 \mathrm{mo}$ & & & & & & & $0.72 * * *$ & $0.56 * * *$ \\
\hline Mothers' & ns & ns & ns & ns & $\mathrm{ns}$ & Ns & $\mathrm{ns}$ & $0.32 * *$ \\
\hline Fathers' & $0.49 * * *$ & $0.28^{*}$ & $0.29 *$ & $\mathrm{~ns}$ & $0.48 * * *$ & Ns & $0.35 * *$ & $0.32 * *$ \\
\hline \multicolumn{9}{|l|}{ HDLC } \\
\hline $6 \mathrm{mo}$ & & & $0.68 * *$ & $0.50 * * *$ & $0.57 * * *$ & $0.45^{* *}$ & $0.54 * * *$ & $0.38 * *$ \\
\hline $12 \mathrm{mo}$ & & & & & $0.75 * * *$ & $0.49 * *$ & $0.51 * * *$ & $0.6^{* * *}$ \\
\hline $18 \mathrm{mo}$ & & & & & & & $0.57 * * *$ & $0.51 * * *$ \\
\hline Mothers' & $\mathrm{ns}$ & ns & $\mathrm{ns}$ & ns & $0.29 *$ & Ns & ns & $0.44 * *$ \\
\hline Fathers' & $0.39 * *$ & $0.40 * *$ & $0.42 * *$ & $\mathrm{~ns}$ & $0.32 *$ & $0.37 * *$ & $\mathrm{~ns}$ & $\mathrm{~ns}$ \\
\hline \multicolumn{9}{|l|}{ LDLC } \\
\hline 6 mo & & & & $0.49 * * *$ & ns & $0.36^{* *}$ & ns & $0.39 * *$ \\
\hline 12 mo & & & & & $0.37 * *$ & $0.51 * * *$ & $0.30 *$ & $0.57 * * *$ \\
\hline $18 \mathrm{mo}$ & & & & & & & $0.48 * *$ & $0.51 * * *$ \\
\hline Mothers' & $\mathrm{ns}$ & $\mathrm{ns}$ & ns & $0.35^{*}$ & $0.31 *$ & Ns & $\mathrm{ns}$ & $0.37 * *$ \\
\hline Fathers' & $\mathrm{ns}$ & $\mathrm{ns}$ & ns & ns & $0.33^{*}$ & $0.27 *$ & ns & $0.28^{*}$ \\
\hline \multicolumn{9}{|l|}{ TC/HDLC } \\
\hline $6 \mathrm{mo}$ & & & $0.92 * * *$ & $0.69 * * *$ & $0.91 * * *$ & $0.55 * * *$ & $0.58 * * *$ & $0.54 * * *$ \\
\hline $12 \mathrm{mo}$ & & & & & $0.93 * * *$ & $0.62 * * *$ & $0.85^{* * *}$ & $0.71 * * *$ \\
\hline $18 \mathrm{mo}$ & & & & & & & $0.86 * * *$ & $0.51 * * *$ \\
\hline Mothers' & ns & ns & ns & $0.30 *$ & ns & $0.31 *$ & ns & $0.49 * * *$ \\
\hline Fathers' & $0.26^{*}$ & $0.39 * *$ & ns & ns & $\mathrm{ns}$ & $0.31 *$ & $\mathrm{~ns}$ & ns \\
\hline \multicolumn{9}{|l|}{ ApoA } \\
\hline $6 \mathrm{mo}$ & & & $0.65 * * *$ & $0.34 *$ & $0.62 * * *$ & $0.31 * *$ & $0.61 * * *$ & $0.38 *$ \\
\hline $12 \mathrm{mo}$ & & & & & $0.78 * * *$ & $0.38 * *$ & $0.65 * * *$ & $0.41 * *$ \\
\hline $18 \mathrm{mo}$ & & & & & & & $0.68 * * *$ & $0.43 * *$ \\
\hline \multicolumn{9}{|l|}{ ApoB } \\
\hline $6 \mathrm{mo}$ & & & $0.41^{* *}$ & $0.64 * * *$ & $0.35 * *$ & $0.55 * * *$ & $0.33^{*}$ & $0.58 * * *$ \\
\hline $12 \mathrm{mo}$ & & & & & $0.57 * * *$ & $0.69 * * *$ & $0.51 * * *$ & $0.68 * * *$ \\
\hline $18 \mathrm{mo}$ & & & & & & & $0.56^{* * *}$ & $0.65 * * *$ \\
\hline \multicolumn{9}{|c|}{ Apo B/apoA-1 $^{2}$} \\
\hline $6 \mathrm{mo}$ & & & $0.93 * * *$ & $0.61 * * *$ & $0.91 * * *$ & $0.56 * * *$ & $0.83 * * *$ & $0.56 * * *$ \\
\hline $12 \mathrm{mo}$ & & & & & $0.96 * * *$ & $0.65 * * *$ & $0.86 * * *$ & $0.66 * * *$ \\
\hline $18 \mathrm{mo}$ & & & & & & & $0.84 * * *$ & $0.64 * * *$ \\
\hline
\end{tabular}

Abbreviations: TC, total cholesterol; HDLC, high-density lipoprotein cholesterol; LDLC, lowdensity lipoprotein cholesterol; apo A-1, apolipoprotein A-1 and apo B, apolipoprotein B ${ }^{1}$ Pearson correlation coefficients, $* \mathrm{p} \leq 0.05, * * \mathrm{p} \leq 0.01$, and $* * * \mathrm{p} \leq 0.001$, ns $=$ not significant.

${ }^{2}$ Maternal and paternal apo B and apoA-1 not available. 
Table 3. Changes in dietary fat intake as percent of energy $(\mathrm{E} \%)$ and as proportion of total fat (\%) from 6-9 mo to $4 \mathrm{y}$ in Swedish children.

\begin{tabular}{|c|c|c|c|c|}
\hline & $\begin{array}{l}\text { 6-9 mo } \\
(n=126)\end{array}$ & $\begin{array}{l}10-14 \mathrm{mo} \\
(n=124)\end{array}$ & $\begin{array}{l}15-18 \mathrm{mo} \\
(n=107)\end{array}$ & $\begin{array}{l}4 y \\
(n=99)\end{array}$ \\
\hline Total dietary fat $(\mathrm{E} \%)$ & $38.6(5.4)$ & $29.4(3.6)$ & $34.6(3.7)$ & $33.2(4.0)$ \\
\hline SAFA (E\%) & $16.1(3.1)$ & $14.5(2.2)$ & $14.4(2.0)$ & $14.8(2.2)$ \\
\hline$(\%)$ & $41.3(2.8)$ & $40.9(3.4)$ & $41.6(3.6)$ & $44.6(3.7)$ \\
\hline MUFA (E\%) & $15.7(2.3)$ & $14.0(1.5)$ & $13.6(1.4)$ & $12.1(1.7)$ \\
\hline$(\%)$ & $40.7(1.8)$ & $40.0(2.4)$ & $39.2(2.2)$ & $36.5(2.5)$ \\
\hline PUFA (E\%) & $6.3(1.2)$ & $5.7(1.1)$ & $5.2(1.6)$ & $4.1(1.0)$ \\
\hline$(\%)$ & $16.5(2.9)$ & $16.2(2.5)$ & $14.9(2.9)$ & $12.3(2.5)$ \\
\hline n-6 fatty acids $(E \%)$ & $\mathrm{na}^{1}$ & $\mathrm{na}^{1}$ & $\mathrm{na}^{1}$ & $3.3(0.92)$ \\
\hline n-3 fatty acids (E\%) & na $^{1}$ & $\mathrm{na}^{1}$ & $\mathrm{na}^{1}$ & $0.86(0.78)$ \\
\hline
\end{tabular}

Abbreviations: SAFA, saturated fatty acids; PUFA, polyunsaturated fatty acid; MUFA, monounsaturated fatty acid.

$5 \quad{ }^{1}$ Data not available.

Data provided as mean (SD). 
Table 4. Factors significantly associated with the children's serum lipid and the ratio of apolipoprotein levels measured when the child was 4 y old, adjusted for gender.

\begin{tabular}{llllll}
\hline Model 1 & & Univariate analysis & 10 \\
\hline Dependent & Independent & $\mathrm{R}^{2}$ & B (s.e.) & \\
\hline TC & Paternal TC & 0.14 & $0.28(0.08)^{* * *}$ & \\
& Maternal TC & 0.07 & $0.17(0.07)^{*}$ & 15 \\
\hline LDLC & Paternal LDLC & 0.09 & $0.22(0.09)^{* *}$ & \\
& Maternal LDLC & 0.09 & $0.24(0.08)^{* *}$ & \\
& & & & 20 \\
\hline HDLC & Duration of breastfeeding & 0.08 & $-0.02(0.01)^{*}$ & 20 \\
& Fat E\% 6 mo & 0.07 & $-0.01(0.003)^{* *}$ & \\
& MUFA E \% 6 mo & 0.06 & $-0.02(0.01)^{* *}$ & \\
& MUFA E\% 15-18 mo & 0.13 & $0.05(0.02)^{* * *}$ & \\
& Maternal HDLC & 0.12 & $0.19(0.06)^{* * *}$ & 25 \\
& Paternal HDLC & 0.05 & $0.13(0.07)^{*}$ & \\
& & & & & \\
& SAFA (\%) 10-14 mo & 0.08 & $0.02(0.01)^{* *}$ & \\
\hline ApoB/apoA-1 ${ }^{1}$ & MUFA (\%) 10-14mo & 0.06 & $-0.02(0.01)^{*}$ & 30 \\
& PUFA (\%) 10-14 mo & 0.06 & $-0.03(0.01)^{*}$ & \\
\hline
\end{tabular}

Abbreviations: TC, total cholesterol; LDLC, low-density lipoprotein cholesterol; HDLC, high-

35 density lipoprotein cholesterol; apo A-1, apolipoprotein A-1 and apo B, apolipoprotein B;

SAFA, saturated fatty acids; PUFA, polyunsaturated fatty acid; MUFA, monounsaturated fatty acid. Independent variables included in the univariate regression model were dietary fat intake (E\%); SAFA, MUFA, and PUFA as E\% and as proportion (\%); duration of breastfeeding (mo); and parental serum lipids (TC, LDLC; and HDLC). ${ }^{1}$ Parental apo B and apoA-1 not available. 
Table 5. Final multivariate analysis of factors associated with serum lipids and ratio of apolipoprotein levels in four-year-old children, adjusted for gender.

\begin{tabular}{|c|c|c|c|c|}
\hline Model 2 & Multivariate reg & analy & & \\
\hline Dependent & Independent & $\mathrm{R}^{2}$ & B(s.e) & 45 \\
\hline TC & Paternal TC & 0.11 & $0.28(0.08)^{* * *}$ & \\
\hline LDLC & Paternal LDLC & 0.07 & $0.23(0.09)^{* *}$ & \\
\hline HDLC & Maternal HDLC & 0.08 & $0.17(0.62)^{* *}$ & \\
\hline Аро B/ароA-1 1 & SAFA $10-14$ mo & 0.92 & $0.02(0.01)^{* *}$ & \\
\hline
\end{tabular}

Abbreviations: TC, total cholesterol; LDLC, low-density lipoprotein cholesterol; HDLC, high-

50 density lipoprotein cholesterol; apo A-1, apolipoprotein A-1 and apo B, apolipoprotein B;

SAFA, saturated fatty acids; PUFA, polyunsaturated fatty acid; MUFA, monounsaturated fatty acid. Independent variables entered into the analyses were variables with $\mathrm{P}<0.05$ in the univariate regression analysis; dietary fat intake (E\%); SAFA, MUFA, and PUFA as E\% and as proportion (\%); duration of breastfeeding (mo); and parental serum lipids (TC, LDLC; and HDLC), ${ }^{1}$ parental

55 apo B and apoA-1 not available. ${ }^{*} p<0.05,{ }^{* *} p<0.01,{ }^{* * *} p<0.001$

60 


\section{FIGURES}

Figure 1 Changes in dietary fat intake as a proportion of total fatty acids (TFA) from 6 mo to $4 \mathrm{y}$

70 of age. The proportion of SAFA increased (mean $3.4 \%, p \leq 0.001$ ) as the proportions of PUFA and MUFA decreased (mean $4.3 \%, \mathrm{p} \leq 0.001$ and mean $5.0 \%, \mathrm{p} \leq 0.001$ ), respectively. 
110

115

120

125 


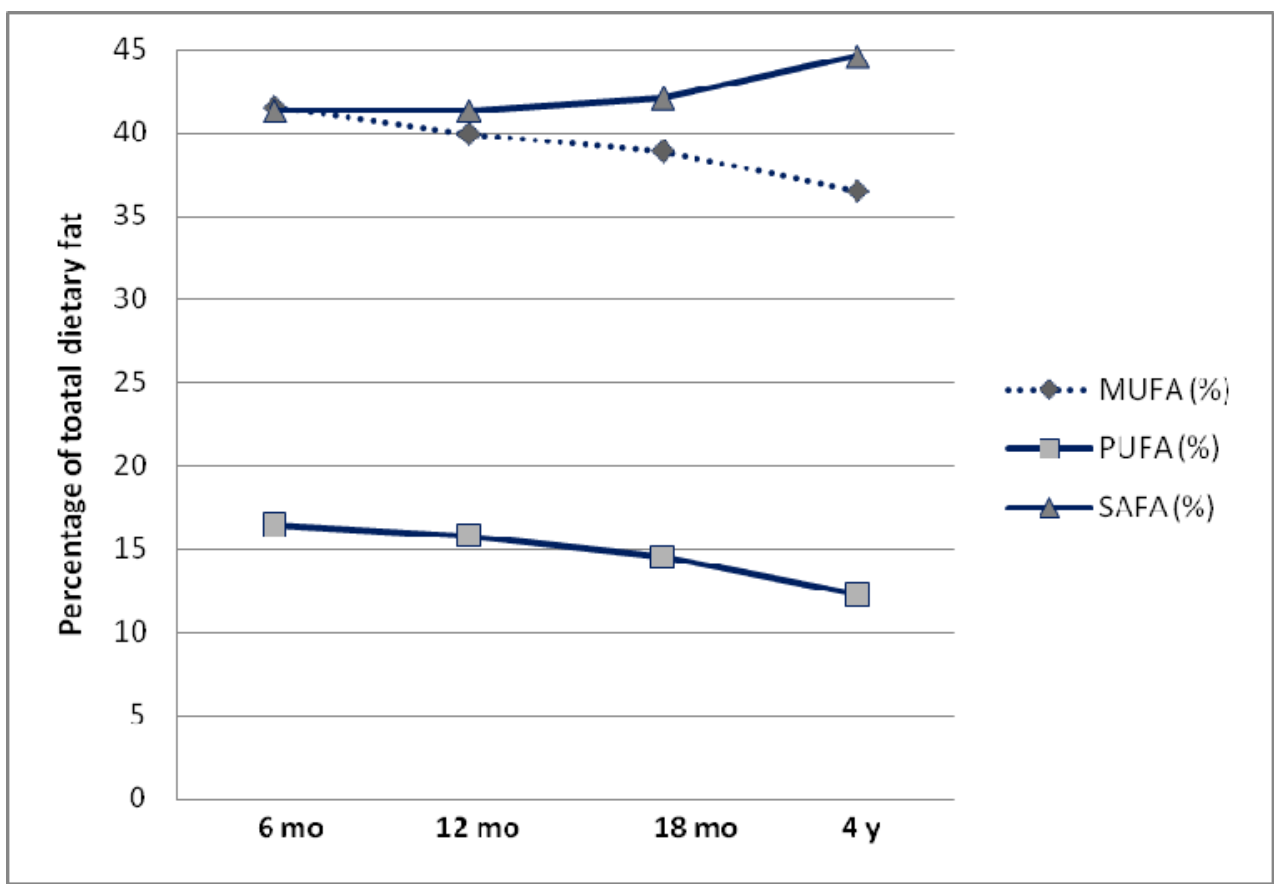


